\title{
造粒固化土を利用した人工海浜の 波浪作用時の挙動に関する遠心模型実験 CENTRIFUGE MODEL TEST ON BEHAVIOUR OF ARTIFICIAL SEASHORE RECLAIMED BY GRANULAR TREATED SOIL IN WAVES
}

\author{
森川嘉之 1 ・桑原拓馬 2 ・早野公敏 3 ・高橋英紀 4 \\ Yoshiyuki MORIKAWA, Takuma KUWAHARA, Kimitoshi HAYANO, \\ and Hidenori TAKAHASHI
}

\author{
1正会員 博 (工） 港湾空港技術研究所 地盤 - 構造部（广239-0826 神奈川県横須賀市長瀬3-1-1） \\ 2 学生会員 横浜国立大学 建設学科（† $240-8501$ 横浜市保土ヶ谷区常盤台79-5)

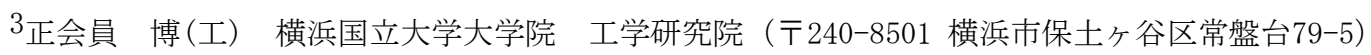 \\ 4 正会員＼cjkstart博(工） 国土交通省関東地方整備局（广221-0053 横浜市神奈川区橋本町 2-1-4）
}

\begin{abstract}
In order to maintain the depth of waterways and sea basins, huge amounts of soft clayey soil are dredged at many ports every year in Japan. In recent years, it has become more difficult to secure disposal areas for dredged soil due to environmental and economical restrictions. The effective use of the dredged soils is therefore required. Granular treated soil, which is dredged clay mixed with cement and polymer, has been developed as a countermeasure against this background and expected to be practical uses for reclamation. This paper reports an applicability of the granular treated soil to a reclamation material of artificial seashore. In this study, a centrifuge model test technique was applied for investigating the behaviour of the artificial seashore reclaimed by high permeable granular treated soil in waves. A centrifuge model test is used for simulating the ground behavior in a proto-type scale by small-sized ground model. The wave generated in centrifugal acceleration was similar to real wind wave.
\end{abstract}

Key Words : granular treated soil, centrifuge test, artificial seashore

\section{1.はじめに}

日本では臨海部における開発により沿岸に工 業・商業施設が建設され，砂浜が減少してきた。近 年では海岸侵食の進行も顕著になり，海辺のレクリ エーションの場として砂浜に対するニーズが高まっ ている。このことから，沿岸域において人工海浜を 造成することが多く検討されている。国土交通省港

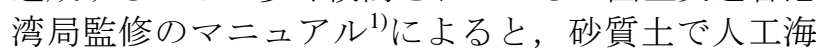
浜を形成することが基本とされているが，海砂の供 給が困難になりつつある。

一方，港湾地域における航路浚渫土の最終処分 場ならびにストックヤードの容量が逼迫しており， 浚渫土の有効利用が望まれている．特に粘土・シル 卜系の浚渫土は有効利用できる箇所が限られており, 新たな利用方法が求められている2). 粘土・シルト 系の浚渫土を直接人工海浜材として用いることも提 案されているが, 浚渫土の長期的な圧密や覆砂が地 盤内に潜り込むことなどの問題点が指摘されており, 何らかの改良が必要である。

柳嶋ら ${ }^{3)}$ は透水性の高い材料を海浜に埋込むこと で海浜の安定化を図れることを模型実験や現場実験
で明らかにしている。また，礫などの透水係数が大 きな材料を海浜材として用いると，常時波浪の来襲 時に細砂が堆積し易いことが石井ら ${ }^{4)}$ や古谷ら ${ }^{5)}$ の 模型実験で観察されている.

高橋ら ${ }^{6 ， 77,8), 99}$ は，軟弱な粘性土に対してセメン 卜と含水比低下材を混合して砂砶程度の粒径の土に 改良した粒状体の有効利用方法について検討を進め ている（以下，作製した粒状体を造粒固化土と称 す）. 造粒固化土の粒径が $1 \sim 10 \mathrm{~mm}$ と比較的大き いことから, 浚渫土に比べて軽量で透水性の高い埋 立地盤を造成することが可能である。高橋ら ${ }^{10)}$ は, 造粒固化土の人工海浜造成への適用性に着目し，造 粒固化土を人工海浜材として用いた地盤の波浪に対 する安定性を遠心模型実験によって調べた。図-1に 示すように海浜材として造粒固化土を利用すれば, 人工海浜を軽量化でき, 海浜下の原地盤が軟弱な場 合でもその沈下量を低減できる。また，造粒固化土 の粒子が一定の強度（本論文と同一材料, 配合で単 粒子強度 $500 \mathrm{kN} / \mathrm{m}^{2}$ 程度 $\left.{ }^{8)}\right)$ を持つことから，造粒固 化土を用いた海浜は浚渫土に比べて圧縮性が低く, 海浜材自体の圧密や覆砂の潜り込みも回避できる. さらに，海浜材部分の透水性が高くなるため，波浪 


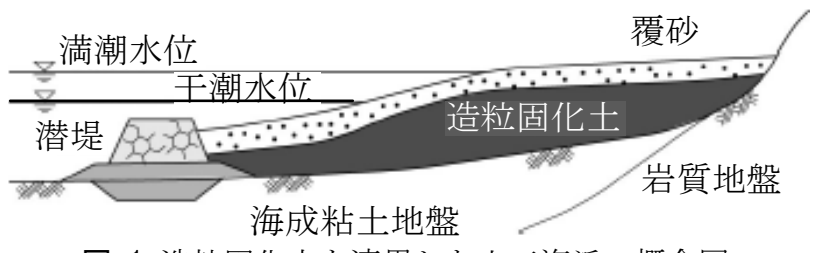

図-1 造粒固化土を適用した人工海浜の概念図

に対する表層材の安定性も高いと考えられる，高橋 $ら^{10)}$ は，遠心模型実験結果をもとに，砂のみの海浜 では波浪載荷後90時間（実物換算時間，実験終了時） まで地表面形状が変動したのに対し，造粒固化土を 用いた海浜では45時間程度と早期に地表面変化が収 束することを示している．また，造粒固化土の高い 透水性が海浜の波浪に対寸る安定性に寄与している ことなどを明らかにしている，ただし，これらは常 時波浪条件および単一の地盤条件での実験結果であ り，さまざまな波浪条件や覆砂層厚の影響などに関 して未検討の部分がある。そこで本研究では，荒天 時を含めた波浪条件に対寸る造粒固化土の人工海浜 への適用性を検討することを目的として，波浪条件 および覆砂層厚を変えて波浪来襲時の海浜の挙動に 関する遠心模型実験を実施した。

\section{2. 遠心場での波浪載荷について}

本研究の特徵は, 遠心力場で波浪載荷実験を 行っている点である. 例えば, 前野賀彦・内田一徳 11), Sekiguchi et al. ${ }^{12)}$, Sassa \& Sekiguchi ${ }^{13)} は$, 遠心 力場において地盤に波浪を作用させ，地盤内の間隙 水圧伝播特性や, 緩く堆積した砂地盤が波浪載荷に よって液状化する現象などを調べている．最近では， 波浪が来襲する護岸や防波堤の挙動についても遠心 模型実験によって調べられている ${ }^{14), 15)}$ 。ただし，本 実験の観察対象である, 勾配を持った海浜に波浪が 来襲する際の地盤挙動を遠心力場で取り扱った研究 事例は, 前述の高橋ら ${ }^{10)}$ の他に無い。 そこで, 本研 究の実験相似則は高橋ら ${ }^{10)}$ に倣うこととした。 以下, その相似則に簡単に触れる。説明中の $N$ は模型の 実物に対する寸法比である。

波浪が海浜地盤に来襲する場合, 地盤の間隙水 圧が繰返し変動し, 水面低下時に発生する上向き浸 透流によって地盤が緩む（拘束圧が低下寸る）とと もに緩んだ砂が流される。地盤の安定性を評価する ためには, 特に過剩間隙水圧の伝播およびそれに伴 う地盤の緩みを適切に再現する必要がある。過剩間 隙水圧伝播現象については, 間隙水の粘性を重力加 速度に対する遠心加速度の比率だけ上昇させること で，伝播に要する時間の相似則と幾何学的な相似則 を $1 / N$ に整合させられることが明らかになっている 12),13). 浮遊・沈降については, 砂粒子に作用寸る重 力（遠心力）, 浮力, 流体抵抗力の相似側をNにす る必要がある. 地盤に $N \mathrm{~g}$ の遠心加速度を加えるこ

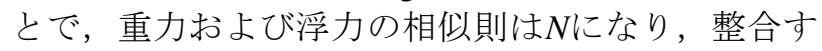

(寸法は実物換算スケール)

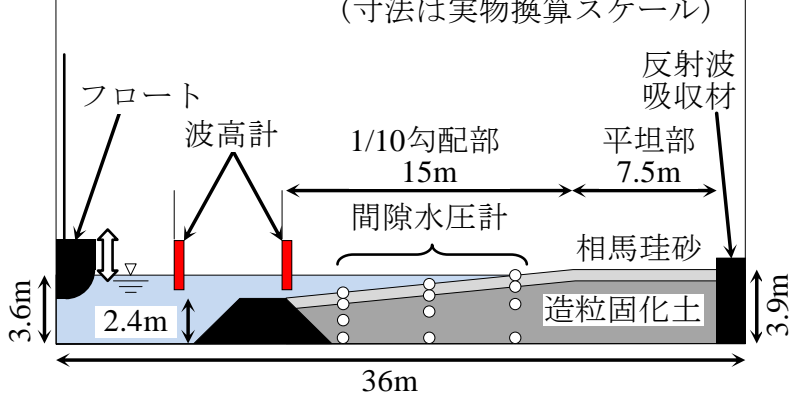

図-2 波浪載荷実験の概略図（例）

る. 流体抵抗力には粘性抵抗力 $R_{1}$ と慣性抵抗力 $R_{2}$ が あり，それぞれ， $R_{1}=6 \pi a v \eta ， R_{2}=0.25 \pi a^{2} v^{2} \rho$ と表す ことができる．ここで， $a$ は砂粒子の半径， $v$ は沈 降速度, $\eta$ は粘性係数, $\rho$ は流体の密度である. 流 体の粘性を水の $N$ 倍に調整することで抗力 $R_{1}$ の相似 則は $N$ とできる。ただし，慣性抵抗力 $R_{2}$ は 1 である. これは, 遠心模型実験では慣性抵抗力を小さく見積 り，粒子が沈降・安定しやすいことになる．ただし， 造粒固化土の $D_{50}=1 \sim 3 \mathrm{~mm}$ を用いて流体抵抗力に対 する $R_{2}$ の寄与率 $\left(R_{2} /\left(R_{1}+R_{2}\right)\right)$ を求めると, 沈降速 度を $10 \mathrm{~mm} / \mathrm{sec}$ とても高々 $1.4 \sim 4.3 \%$ あり, 流体 抵抗力全体として問題はないと考えられる.掃流は Shields数で説明され, 重力加速度が $30 \mathrm{~g}$ の遠心力場 ではShields数は1/30 となる. 定量的にその効果を評 価することは難しいが，このShields数の過小評価は， 粘性流体を用いて摩擦係数を大きくすることである 程度解消されると考えられる。

遠心力場において波浪変形や乱流の発達, それ に呼応した漂砂の挙動に関する全ての相似則を満足 することは難しい. しかしながら，このことは重力 場の模型実験についても同じであり，模型実験では 観察したい挙動の相似則を合わせることが重要であ る. 本実験では, 着目点の地盤内応力や過剩間隙水 圧の伝播現象の相似則は整合しており, 遠心模型実 験は有用な実験手法であると考えられる。

\section{3. 実験条件}

\section{（1）模型断面および地盤材料}

遠心力場での波浪載荷実験の概略図を図-2に示 す. 人工海浜を想定した模型地盤は内寸高さ $60.0 \mathrm{~cm}$ $\times$ 幅 $120.0 \mathrm{~cm} \times$ 奥行 $20.0 \mathrm{~cm}$ の鋼製試料容器に作成し た. 実験は $30 \mathrm{~g}$ の遠心力場で実施したため, 実物換 算寸法は高さ $18.0 \mathrm{~m} \times$ 幅 $36.0 \mathrm{~m} \times$ 奥行 $6.0 \mathrm{~m}$ である.

地盤材料は, 粒径4.75 9.5 mmの砕石, 相馬珪砂 5 号および造粒固化土である。造粒固化土の母材は 川崎粘土（川崎港で採取された海成粘土），固化材 は普通ポルトランドセメント, 含水比低下材は水溶 性ポリマー（ポリアクリル酸中和物）である.

造粒固化土作製にあたっては，まず，川崎粘土 を液性限界よりも少し高い含水比 $60 \%$ に調整, 十分 に擋汼した。 そしてポリマーを添加（母材に対する 湿潤重量比 $0.1 \%$ ）し，さらに2分間摚找した。見か 


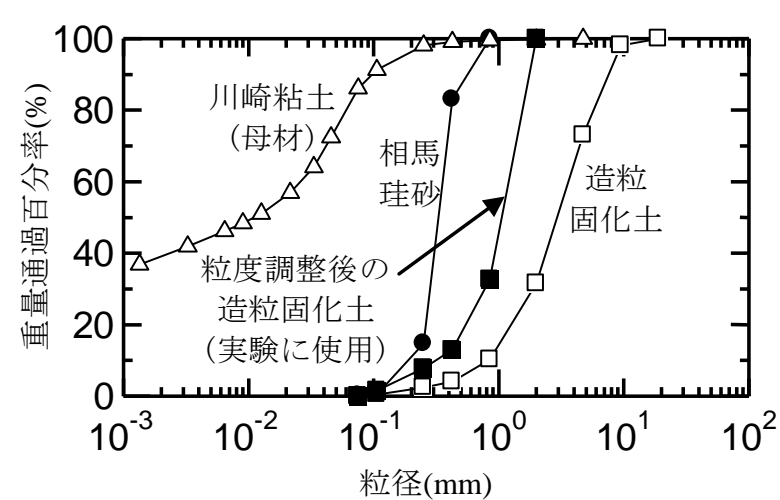

図-3 地盤材料の粒度曲線

表-1 地盤条件

\begin{tabular}{|c|c|c|c|}
\hline ケース & 海浜材 & 覆砂層厚 & 潜堤の補強 \\
\hline $\mathrm{S} 60 \mathrm{G}$ & 造粒固化土 & $60 \mathrm{~cm}$ & なし \\
\hline $\mathrm{S} 60 \mathrm{G}(\mathrm{Re})$ & 造粒固化土 & $60 \mathrm{~cm}$ & あり \\
\hline $\mathrm{S} 90 \mathrm{G}(\mathrm{Re})$ & 造粒固化土 & $90 \mathrm{~cm}$ & あり \\
\hline $\mathrm{SS}(\mathrm{Re})$ & 相馬珪砂 & - & あり \\
\hline
\end{tabular}

けの含水比が低下したところで，セメントを添加 （母材に対する湿潤重量比 $5 \%$ ）し，同様に攪拌機 で5分間攪拌した。 その後，約1時間気中で放置し， 再び1分間撹汼した。放置後の擋拌は, 粒状体同士 の付着が見られたため，それをほぐすために実施し た。そして，作製した造粒固化土にラップをかけ， 室温 $20^{\circ} \mathrm{C}$ の恒温室で28日以上養生した.

相馬珪砂5号，造粒固化土およびその母材である 川崎粘土の粒度曲線を図-3に示す。作製時の造粒固 化土の粒径は，おおむね 1 お $10 \mathrm{~mm}$ であった。今回 の実験では，投入時の分級による細粒分溜まりの形 成など最悪の場合を想定し, 造粒固化土を $2 \mathrm{~mm}$ 以 下の粒子に粒度調整した。図-3からも分かるとおり, 粒度調整後の造粒固化土でも平均粒径は相馬珪砂の 三倍程度となっている。また, 土粒子密度は造粒固 化土が $2.740 \mathrm{~g} / \mathrm{cm}^{3}$ ，相馬珪砂が $2.645 \mathrm{~g} / \mathrm{cm}^{3}$ であった。

\section{（2）模型地盤作成方法}

地盤条件を表-1に示す。実験では海浜材，覆砂 の層厚を変えて実験を行っている．ケースS60G以外 は潜堤に市販の網戸（ビニール製）による補強を施 してある（図-4）。

模型地盤の作成方法は次の通りである。まず乾 燥した容器の背面にメンブレン, 前面（ガラス面） にモビロンシートを貼付し容器側面と地盤の摩擦低 減を図った。次に法留め構造物としての潜堤を砕石 で作製した。砂粒子や造粒固化土の流出を防ぐフィ ルター材として，潜堤岸側の側面にガーゼを敷いた. 次に底面の計測器を設置し, 地盤材料となる造粒固 化土，または相馬珪砂を投入した。造粒固化土はス コップを用いて敷き詰めるようにして投入した。そ して，投入した造粒固化土に対して，遠心場での沈 下を防ぐために予圧密を行った。予圧密にはベロフ ラムシリンダーを用い，予圧密圧力は $40 \mathrm{kN} / \mathrm{m}^{2}$ であ る. 予圧密圧力は遠心場における造粒固化土の自重

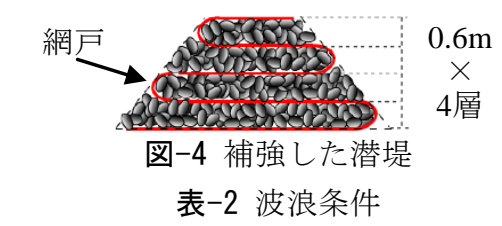

\begin{tabular}{|c|c|c|c|c|c|}
\hline \multicolumn{2}{|c|}{ 荒天時 (Wave1) } & \multicolumn{2}{c|}{ 静穏時 (Wave2) } \\
\hline 波高 $(\mathrm{m})$ & 周期 $(\mathrm{sec})$ & $\mathrm{C}$ 值 & 波高 $(\mathrm{m})$ & 周期 $(\mathrm{sec})$ & $\mathrm{C}$ 值 \\
\hline $1.3-1.6$ & 5.0 & $6.2-8.2$ & $0.6-0.7$ & 5.0 & $2.8-3.3$ \\
\hline
\end{tabular}

と覆砂の土被り圧の大きさから決定した。相馬珪砂 の投入には相対密度を均一にするため空中落下法を 用いた。その相対密度は約 $73 \%$ あっった。斜面は相 対密度を乱さないようにすり切って成形した。覆砂 の作製後, 最後に重力場で模型地盤の岸側下方から 十分に脱気した粘性流体を通水した。本実験では $30 \mathrm{~g}$ の遠心力場で波浪載荷を行うことから，幾何学 的相似則と時間的相似則を一致させるため, 流体の 粘性係数を純水の30倍となるように調整してある.

\section{（3）模型実験方法}

実験では，模型地盤に遠心加速度 $30 \mathrm{~g}$ を加えた状 態で波浪を地盤に入射した。入射した波浪の詳細に ついては次節で後述する。使用した遠心模型実験装 置は港湾空港技術研究所が所有する装置 ${ }^{16)}$ である.

遠心力場で波浪を入射しながら模型地盤側面を 動画撮影し, この撮影画像から地表面の変形を求め た。また, 小型の容量式波高計によって波高を計測 し，地盤内に埋め込んだ小型の間隙水圧計で間隙水 圧を計測した。センサー群の設置位置は図-2を参照 されたい。これらの計測項目から, 波浪載荷時の地 盤の挙動について検討した.

\section{（4）波浪条件}

実験ケースを表-2に示す。実験では，荒天時を 想定した波浪（以降Wave1 と呼ぶ）を実物換算で 60 時間与えた後，静穏時を想定した波浪（以降Wave2 と呼ぶ）を実物換算で120時間与えた。これは一度 侵食を受けた海浜に堆積が生じるような海浜地形変 化サイクルの再現を試みたものである。Wave1は Wave2の約2倍の波高である。また周期はいずれも 実物換算で5秒である。なお, 表中のC值は波浪に よる海浜の地表面変化を分類するパラメータで, 次 式 ${ }^{17)}$ で定義される.

$$
C=\frac{H_{0}}{L_{0}}(\tan \beta)^{0.27}\left(\frac{d}{L_{0}}\right)^{-0.67}
$$

ここで， $H_{0}$ は沖波波高， $L_{0}$ は沖波波長， $\tan \beta$ は海底 勾配， $d$ は底質粒径である。底質粒径は相馬珪砂の 平均粒径0.32 (mm)で代表させ, 沖波波高, 及び沖 波波長は実測データから浅水変形を考慮して算出し た值を用いた。上式の右辺には海浜および波浪に関 するパラメータが含まれている。上式において波浪 条件を固定すると, $C$ 值はその海浜の侵食されやす さ（堆積する場合を含む）を表すパラメータとなる。 


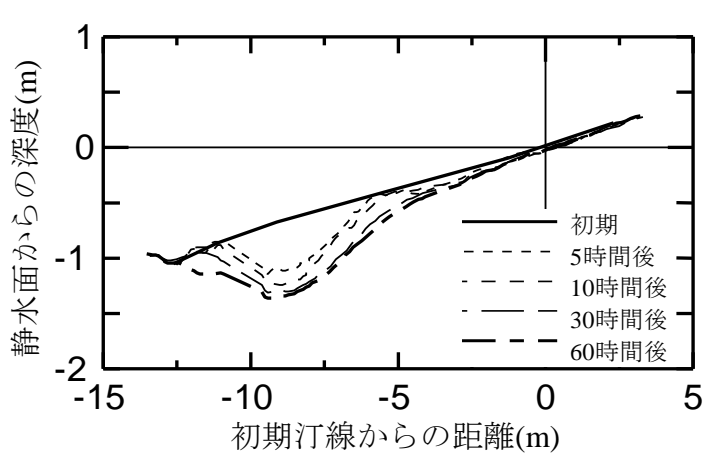

(a) $\mathrm{S} 60 \mathrm{G}(\mathrm{Re}) （$ 造粒固化土，覆砂 $60 \mathrm{~cm}$ )

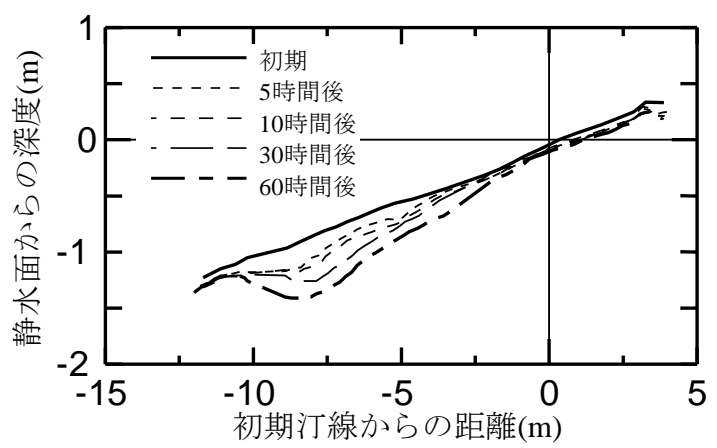

(b) S90G(Re)（造粒固化土，覆砂 $90 \mathrm{~cm}$ )

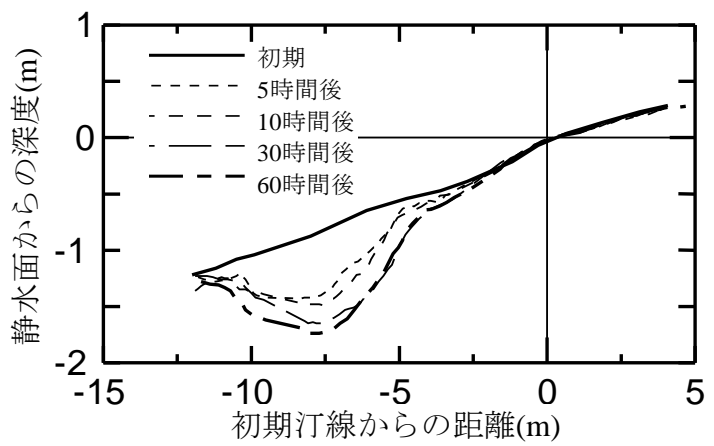

(c) SS(Re)（相馬珪砂）

図-5 地表面変動（荒天時）

今回の実験では海浜勾配および地表面の材料は一定 であるので，波浪条件が $C$ 值を左右することになる. Sunamura and Horikawa ${ }^{17)}$ によると，C>8の場合に 侵食， $C<4$ の場合に堆積が生じる波浪条件となる。

\section{4. 遠心模型実験結果}

\section{（1）地表面形状の変化}

\section{a) 荒天時}

Wave1（荒天時）の波浪載荷中に撮影した画像か ら読み取った地表面の変化を図示したのが図-5であ る。なお，S60Gにおいて，波浪載荷途中で潜堤が 海側へ崩壊し，造粒固化土および覆砂が流失したた め，S60Gの結果は図示していない。横軸は初期汀 線からの距離（陸側が正）を，縦軸は初期水面から の深度を実物寸法換算で表している。各ケースを比 較すると，相馬珪砂のみのケース SS(Re)において， 波浪載荷初期に大きく海浜が削られ, 載荷終了時に 他のケースよりも大きくなっていることが分かる.

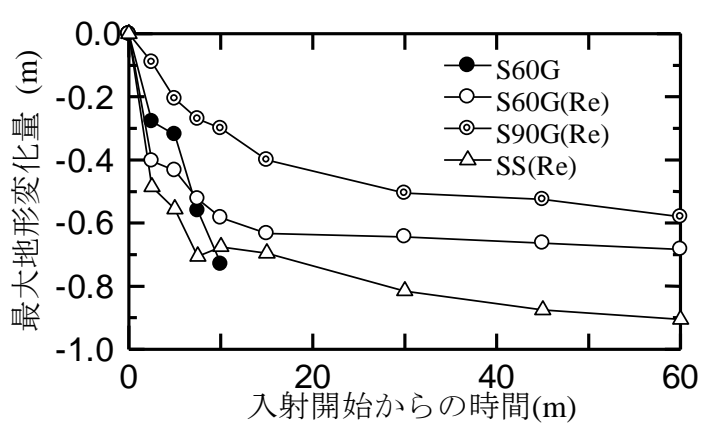

図-6 最大地盤高変化量

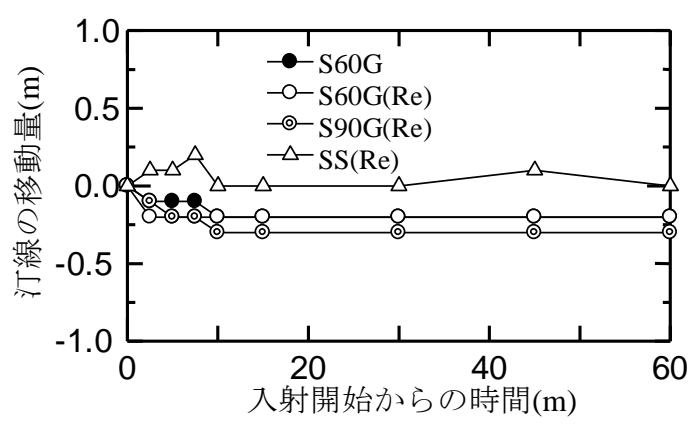

図-7 汀線の移動量（荒天時）

波浪載荷開始後5時間までに削られた深さを見ると, S60G(Re)やS90G(Re)において載荷終了時までに削 られた深度と同程度となっている。ただし，大きく 削られる範囲（今回の実験では-5〜-10m付近）は, いずれのケースもほぼ同じで，その範囲はあまり変 化しなかった。また，各時間において最も地形変化 の大きかった地点もほぼ一定していた。図一6は，各 計測時間における最大地形変化量を示したものであ る。潜堤の破壊したケースを除き，造粒固化土を用 いたケースの最大地形変化量の方が小さくなってい る。また，地形変化速度の大きい10時間後までの間 を見ると，造粒固化土を用いたケース $\mathrm{S} 60 \mathrm{G}(\mathrm{Re})$ や S90G(Re)で地形変化の進行が小さいことがわかる なお， S60G(Re)のケースでは，地形変化が 15 時間 後に $60 \mathrm{~cm}$ に達し, 収束している。これは覆砂層厚 と等しく，造粒固化土の露出によって地形変化の進 行が抑制されたように見える。しかし，覆砂層厚が $90 \mathrm{~cm}$ の $60 \mathrm{G}(\mathrm{Re})$ もほぼ同等の地形変化量でその進 行が収束している。このことから，S60G(Re)の地 形変化の収束は，侵食されるべき砂の㶾失（造粒固 化土の露出）のためではないと考えられる.

図-7は汀線の移動量を示している。相馬珪砂の みのケース $\mathrm{SS}(\mathrm{Re})$ の汀線が変化していないのに対し て，造粒固化土を用いたケース S60G(Re)や S90G(Re)では若干陸側へ後退している.ただし, その量は模型スケールで $1 \mathrm{~cm}$ 弱である。海浜勾配が 1/10であるから，高さの差は $1 \mathrm{~mm}$ 程度となる．撮影 画像の解像度や読み取り時の誤差などを考慮すると, 絶対值は有意な值ではないと考える。

\section{b) 静穩時}

実物換算でWave1（荒天時）を60時間載荷した後， Wave2（静穏時）を120時間載荷した。なお，造波 


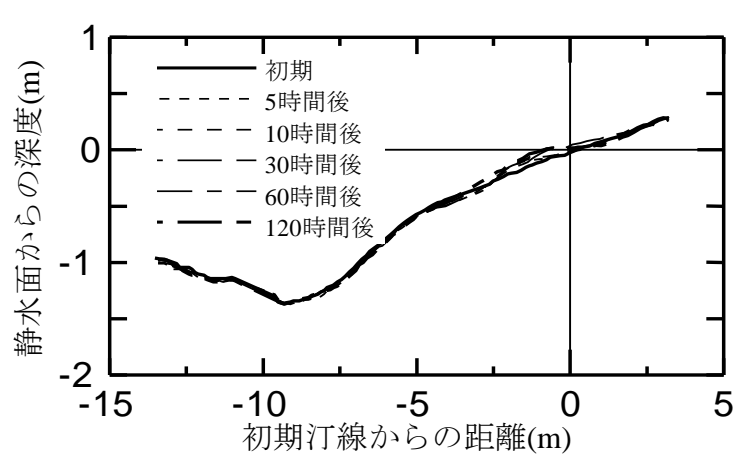

(a) $\mathrm{S} 60 \mathrm{G}(\mathrm{Re}) （$ 造粒固化土，覆砂 $60 \mathrm{~cm}$ )

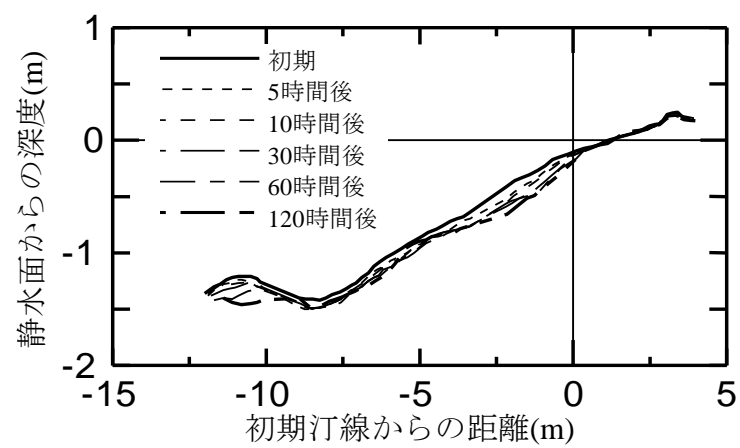

(b) $\mathrm{S} 90 \mathrm{G}(\mathrm{Re}) （$ 造粒固化土，覆砂 $90 \mathrm{~cm}$ )

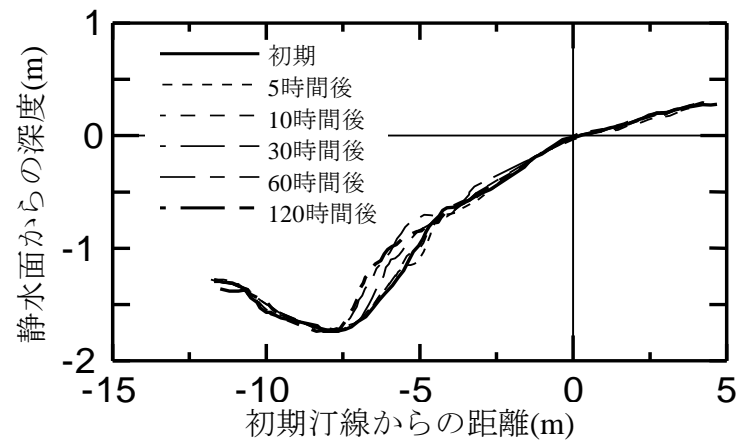

(c) $\mathrm{SS}(\operatorname{Re}) （$ 相馬珪砂）

図-8 地表面変動（静穏時）

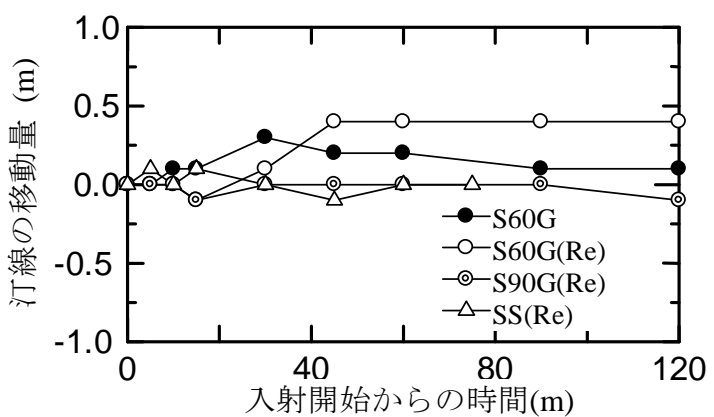

図-9 汀線の移動量（静穏時）

装置の設定を変更するため, Wave1載荷終了後に遠 心載荷装置を一旦停止したが，模型地盤の整形など は行っていない。図-8は図-5と同様に載荷中に撮影 した画像から読み取った地表面の変化である。いず れのケースにおいてもほとんど地表面形状が変化し ていないのが分かる。初期状態が異なるために直接 比較することは難しいが，S90G(Re)ではC值が堆積 型の波浪を載荷しているにもかかわらず，若干侵食 が進行している。逆にSS(Re)では，荒天時の波浪で

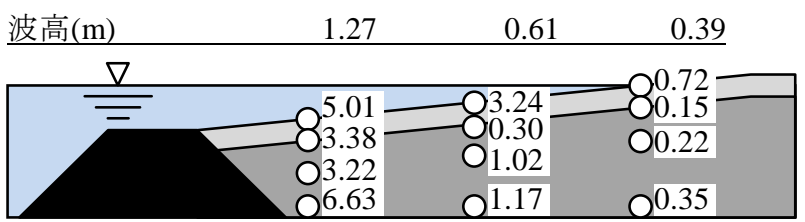

(a) S60G（造粒固化土，覆砂 $60 \mathrm{~cm}$ ，潜堤補強なし） 波高 $(\mathrm{m})$

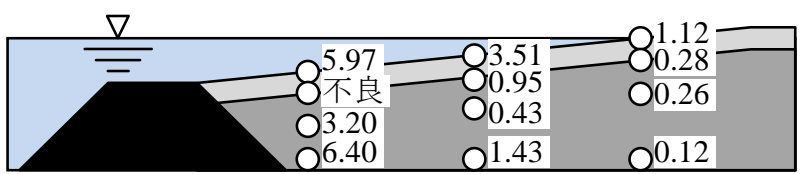

(b) S60G(Re)（造粒固化土，覆砂 $60 \mathrm{~cm}$ ，潜堤補強） 波高 $(\mathrm{m})$

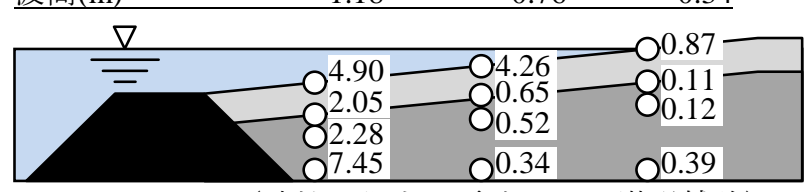

(c) S90G $(\operatorname{Re}) （$ 造粒固化土，覆砂 $90 \mathrm{~cm}$ ，潜堤補強） 波高 $(\mathrm{m})$

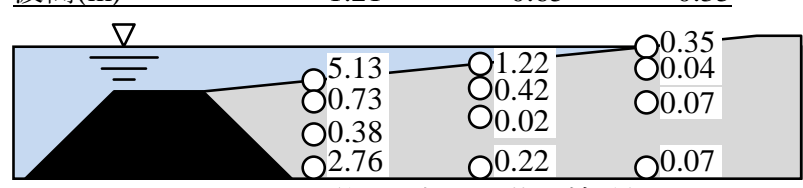

(d) SS $(\operatorname{Re}) （$ 相馬珪砂，潜堤補強）

図-10 地盤内の間隙水圧の変動幅 (単位: $\mathrm{kN} / \mathrm{m}^{2}$ )

大きくポケット状に削られた急勾配の部分において 地形の回復が見られる。

汀線変化を示した図-9を見てもあまり大きな移 動は見られなかった。S60G(Re)において若干の回 復が見られるが，図-7と同様に絶対值は小さかった。

\section{（2）間隙水圧の変化}

各計測位置におけるWave1 載荷後5 時間の過剩間 隙水圧の応答振幅を図-10に示す。いずれのケース も潜堤に近い底部における応答振幅が比較的大きく なっているが，同じ位置で比較すると，造粒固化土 を用いたS60G(Re)やS90G(Re)の方が相馬珪砂のみ のSS(Re)よりも大きくなっている.このことから， 海浜材の透水性の大きいS60G(Re)やS90G(Re)では, 潜堤および海浜材内に波浪に追随する間隙水の移動 が生じ，海浜の陸側深部にも水圧が伝播したものと 考えられる。潜堤に補強を施した S60G(Re)や $\mathrm{S} 90 \mathrm{G}(\mathrm{Re})$ で潜堤の崩壊が見られなかったことから， 無補強のS60Gのケースで潜堤が海側へ崩壊したの は，造粒固化土の高い透水性により潜堤内部に発生 する強い戻り流が一因であると推測される。また， 海浜地盤全体で比較しても造粒固化土を用いた海浜 では水圧変動が大きいことがわかる。図-11に潜堤 に近い計測位置における地表面付近の動水勾配の変 化を示す. 図示したのはWave1入射開始5時間後の データである。海浜材に造粒固化土を用いたケース では，砂のみのケースに比べて動水勾配が約 $1 / 2$ に 低減されている。これは，図-10にも示したように， 造粒固化土を用いたケースでは深い領域でも地表面 の変動に準じて比較的大きな変動が生じていたこと 


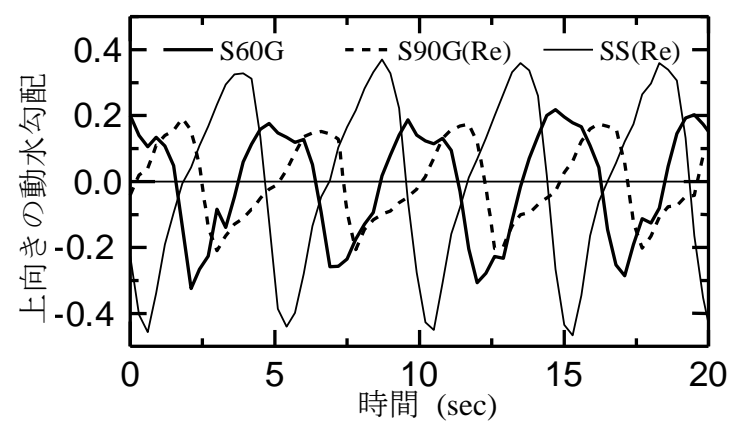

図-11 地表面付近の動水勾配の変化

と対応している。また，Wave1入射開始5時間後の 地形変化（図-6）の速度が砂のみのケース SS $(\mathrm{Re})$ で 大きいのは，造粒固化土を用いたケースに比べて大 きな動水勾配により，地表面付近が比較的不安定に なったためと思われる。

\section{5.おわりに}

本研究では，造粒固化土の人工海浜への適用性 を検討することを目的として，波浪来襲時の海浜の 挙動に関する遠心模型実験を実施した。得られた結 果を以下にまとめる.

・荒天時を想定した波浪載荷した場合，削られる海 浜の範囲はケースに依らずほぼ同じであり，最も 地形変化の大きい位置も一定していた。しかし, 波浪載荷初期時の地形変化速度や載荷終了時の地 形変化量は，海浜材に造粒固化土を用いたケース の方が小さかった.

・荒天時を想定した波浪載荷に引続き，静稳時を想 定した波浪載荷を実施した。これは一度侵食を受 けた海浜に堆積が生じるような海浜地形変化サイ クルの再現を試みたものであるが，汀線付近の地 表面はいずれの海浜材でも変化が非常に小さかっ た。ただし，相馬珪砂を海浜材としたケースにお いて，荒天時の波浪で大きくポケット状に削られ た急勾配の部分に堆積が見られた。

- 荒天時の波浪載荷時の間隙水圧の変動は，造粒固 化土を用いたケースの方が相馬珪砂のみのケース よりも大きかった。造粒固化土を用いたケースで は，潜堤を通じて水圧が伝播していると考えられ る。また，造粒固化土を用いたケースでは深度の 大きい領域でも地表面の変動に準じて比較的大き な変動が生じる。その結果，表層部に生じる動水 勾配が小さくなる傾向にあった。特に，水位低下 時の上向きの動水勾配の低減が，底質の浮遊の抑 制，ひいては波浪載荷初期の地形変化速度の低減 の要因となった可能性がある.

以上のようなことから，造粒固化土を海浜材と して用いた場合，荒天後の地形回復という効果は得 られなかったが，荒天時の侵食速度が低減されるこ とが分かった。このように造粒固化土を用いた人工 海浜は，常時波浪に対してだけでなく，荒天時の波 浪に対しても一定の安定性向上の効果を有している.
したがって，造粒固化土の人工海浜材としての適用 性は高いと考えられる。

\section{参考文献}

1) 海の自然再生ワーキング・グループ: 海の自然再生ハ ンドブック，国土交通省港湾局，2003.

2) 国土交通省港湾局：港湾の技術開発にかかる行動計画 〜安全で活力ある持続可能な社会の実現を目指して〜， 国土交通省港湾局, 17 p., 2005 .

3) 柳嶋慎一, 佐藤勝弘, 原隆, 齋藤正文, 岩佐直人, 堀 謙吾，長谷川厫，長谷川準三：透水層埋設による海浜 安定化工法の開発，港湾空港技術研究所報告，Vol. 42, No. 1, pp. 1-113, 2003.

4) 石井秀雄, 中村友和, 宇多高明, 大木康弘, 熊田貴之, 芹沢真澄 : 茨城県神向寺海岸での粗粒材養浜による砂 浜の安定化，海洋開発論文集，Vol. 22，pp. 887-892, 2006.

5) 古谷真広, 小林昭男, 宇多高明, 野志保仁, 清水達也, 遠藤将利：礫浜における細砂中砂の挙動に関する実験 的研究, 海洋開発論文集, Vol. 25, pp. 1113-1118, 2009.

6) 高橋英紀, 市川栄徳, 大草陽太郎, 早野公敏, 森川嘉 之：貧配合セメント造粒砂の力学特性に関する一検討, 海洋開発論文集，Vol. 25，pp. 215-220， 2009.

7) 高橋英紀, 大草陽太郎, 早野公敏, 森川嘉之: 遠心力 場における造粒固化土の岸壁背後地盤への適用性の検 討，地盤工学シンポジウム論文集，No. 54，pp. 519526, 2009.

8) 高橋英紀，森川嘉之，市川栄徳，早野公敏，大草陽太 郎：貧配合セメント造粒固化土の圧縮特性および支持 力特性に関する模型実験, 土木学会論文集 C, Vol. 66, No. 2, pp. 236-249, 2010.

9) 高橋英紀，大草陽太郎，早野公敏，森川嘉之：造粒固 化土を埋立材に用いた岸壁の振動模型実験, 地盤工学 ジャーナル, Vol. 5, No. 2, pp. 231-240, 2010.

10) 高橋英紀, 小川慧, 早野公敏, 森川嘉之, 二宮裕介, 造粒固化土を利用した人工海浜の波浪安定性に関する 遠心模型実験，海洋開発論文集，Vol. 26，pp. 687-692， 2010.

11) 前野賀彦, 内田一徳：遠心載荷装置による波浪を受 ける海底地盤内応力場の再現, 海岸工学論文集, Vol. 37, pp. 754-758, 1990.

12) Sekiguchi, H., Kita, K., and Okamoto, O.: Response of poroelastoplastic beds to standing waves, Soils and Foundations, Vol. 35, No. 3, pp. 31-42, 1995.

13) Sassa, S. and Sekiguchi, H.: Wave-induced liquefaction of beds of sand in a centrifuge, Geotechnique, Vol. 49, No. 5, pp. 621-638, 1999.

14) 馬場慎太郎，三宅達夫，金夏永，鶴ヶ崎和博 : 波 地盤・構造物の新しい実験手法, 海岸工学論文集, Vol. 49, pp. 1536-1540, 2002.

15) 三宅達夫，角田紘子，前田健一，坂井宏隆，今瀬達 也: 津波の遠心力場における実験手法の開発とケーソ ン式防波堤への適用，海洋開発論文集，Vol. 25，pp. 87-92, 2009.

16) 北詰昌樹：新遠心模型実験装置の開発と研究への適 用，港湾技術研究所資料，No. 812，35p.，1995.

17) Sunamura, T. and Horikawa, K.: Two-Dimensional Beach Transformation Due To Waves, Proc. of 14th Coastal Eng. Conf., ASCE, pp. 920-937, 1974. 